\title{
COVID-19 in MS
}

\section{Initial observations from the Pacific Northwest}

James D. Bowen, MD, Justine Brink, DO, MPH, Ted R. Brown, MD, MPH, Elisabeth B. Lucassen, MD, Kyle Smoot, MD, Annette Wundes, MD, and Pavle Repovic, MD, PhD

Neurol Neuroimmunol Neuroinflamm 2020;7:e783. doi:10.1212/NXI.0000000000000783

Coronavirus disease 2019 (COVID-19), caused by the severe acute respiratory syndrome coronavirus-2 (SARS-CoV-2), is marked by a wide range and severity of symptoms. Most patients have mild to moderate symptoms, whereas $10 \%-15 \%$ require hospitalization. Mortality is higher with cardiovascular disorders, diabetes, and older age. ${ }^{1}$

Little is known about the clinical features of COVID-19 in the context of multiple sclerosis (MS), where some disease-modifying therapies (DMTs) may lead to immunocompromised state. Regarding the use of MS DMTs in the context of the COVID-19 pandemic, clinicians have had to make inferences, based on the DMT's mechanism of action and clinical trial data on infections, whether to continue, stop, or change the therapy in their patients with MS. ${ }^{2}$

Here, we report our initial experience with COVID-19 among 8 patients with MS (table). The earliest case in our series occurred abroad in the early days of the COVID-19 outbreak. Other infections occurred locally in Washington and Oregon. The source of infection was a close contact in 2 cases, residential nursing facility in 2 cases, travel in 1, but not identified in 3 cases. Our case series consists mostly of female patients (6 of 8), aged 35-74, and most of whom had relapsingremitting MS (5 of 8). Most of the patients had lower disability (Expanded Disability Status Scale [EDSS] score 1-3.5), with 2 exceptions (EDSS 7.5 and 8.5). Two patients were on injectable agents ( 1 interferon and 1 glatiramer), 2 on dimethyl fumarate (DMF), 1 on teriflunomide (TFL), and 2 on fingolimod (FNG), whereas 1 patient was not on DMT. None had a relapse or systemic corticosteroids recently. Neither of the patients on DMF had lymphopenia at baseline. Patients with FNG had lymphopenia $(0.8$ and $0.6 \mathrm{~K} / \mathrm{ul})$ at presentation and 6 months before COVID-19 infection, respectively.

The most common presenting symptoms of COVID-19 in this cohort were fever (7 of 8), cough ( 6 of 8 ), and headache (4 of 8 ). Less common symptoms were sneezing (2), anosmia (2), fatigue (2), nausea (1), chills (1), and disequilibrium (1). One patient never developed fever. Two patient had dyspnea and altered mental status. We suspect that their altered mental status was probably due to hypoxia, although direct effect of SARS-CoV-2 on CNS could not be excluded.

COVID-19 diagnosis was confirmed by RT-PCR on a sample obtained by nasopharyngeal swab between 1 and 14 days after symptom onset, reflecting the challenges with laboratory testing at the time. One patient's diagnosis was not confirmed by RT-PCR, but her spouse, who had the same symptoms, tested positive 2 days earlier, so we believe that COVID-19 diagnosis is most likely accurate.

COVID-19 symptoms lasted 6-28 days. Three patients were hospitalized, one of them primarily for observation. Although symptomatic, 2 patients on FNG stopped taking their medication for 2 and 4 days (while febrile). The patient on interferon missed 1 dose. Patients on glatiramer acetate and DMF continued their treatment without interruption.
Correspondence

Dr. Repovic

pavle.repovic@swedish.org

\section{MORE ONLINE}

\section{COVID-19 Resources}

For the latest articles, invited commentaries, and blogs from physicians around the world

NPub.org/COVID19

From the Swedish Multiple Sclerosis Center (J.D.B., P.R), Seattle, WA; Providence Multiple Sclerosis Center (J.B., E.B.L., K.S.), Portland, Oregon; EvergreenHealth Multiple Sclerosis Center (T.R.B.), Kirkland; and University of Washington Multiple Sclerosis Center (A.W.), Seattle.

Go to Neurology.org/NN for full disclosures. Funding information is provided at the end of the article. 
Table Clinical features of MS and COVID-19

\begin{tabular}{|c|c|c|c|c|c|c|c|c|c|}
\hline Age & Gender & $\begin{array}{l}\text { MS } \\
\text { diagnosis }\end{array}$ & EDSS & DMT & $\begin{array}{l}\text { COVID-19 } \\
\text { symptoms }\end{array}$ & $\begin{array}{l}\text { Days from } \\
\text { symptom onset } \\
\text { to }+ \\
\text { test (PCR) }\end{array}$ & Comorbidities & $\begin{array}{l}\text { DMT } \\
\text { modification/ } \\
\text { interruption }\end{array}$ & Outcome \\
\hline 35 & $\mathrm{~F}$ & RRMS & 2.0 & DMF & Fever and dry cough & 2 & DM and asthma & None & $\begin{array}{l}\text { Full } \\
\text { recovery }\end{array}$ \\
\hline 43 & M & RRMS & 2.5 & FNG & $\begin{array}{l}\text { Fever, cough, } \\
\text { headache, } \\
\text { and sneezing }\end{array}$ & 12 & None & $\begin{array}{l}\text { Held } 4 \text { d while } \\
\text { febrile }\end{array}$ & $\begin{array}{l}\text { Full } \\
\text { recovery }\end{array}$ \\
\hline 46 & $\mathrm{~F}$ & RRMS & 2.0 & IFN & $\begin{array}{l}\text { Fever, cough, and } \\
\text { fatigue }\end{array}$ & Not tested ${ }^{a}$ & None & Held one dose & $\begin{array}{l}\text { Recovering } \\
\text { (cough) }\end{array}$ \\
\hline 50 & $\mathrm{~F}$ & RRMS & 1.0 & DMF & $\begin{array}{l}\text { Fever, dry cough, } \\
\text { headache, fatigue, } \\
\text { anosmia, nausea, } \\
\text { and disequilibrium }\end{array}$ & 8 & None & None & $\begin{array}{l}\text { Full } \\
\text { recovery }\end{array}$ \\
\hline 53 & $\mathrm{~F}$ & RRMS & 2.0 & GA & $\begin{array}{l}\text { Headache, } \\
\text { sneezing, } \\
\text { and anosmia }\end{array}$ & 14 & Obesity & None & $\begin{array}{l}\text { Full } \\
\text { recovery }\end{array}$ \\
\hline 55 & $\mathrm{~F}$ & SPMS & 7.5 & TFL & $\begin{array}{l}\text { Fever, cough, } \\
\text { dyspnea, } \\
\text { and altered mental } \\
\text { status }\end{array}$ & 7 & Myotonic dystrophy & Stopped & Fatal \\
\hline 56 & $\mathrm{~F}$ & SPMS & 3.5 & FNG & $\begin{array}{l}\text { Fever, headache, } \\
\text { and chills }\end{array}$ & 4 & None & $\begin{array}{l}\text { Held } 2 \mathrm{~d} \text { while } \\
\text { febrile }\end{array}$ & $\begin{array}{l}\text { Full } \\
\text { recovery }\end{array}$ \\
\hline 74 & M & SPMS & 8.5 & None & $\begin{array}{l}\text { Fever, cough, } \\
\text { dyspnea, } \\
\text { and altered mental } \\
\text { status }\end{array}$ & 1 & $\begin{array}{l}\text { CAD, HTN, DM, COPD, } \\
\text { and cardiomyopathy }\end{array}$ & Not applicable & Fatal \\
\hline
\end{tabular}

Abbreviations: $C A D=$ coronary artery disease; $C O P D=$ chronic obstructive pulmonary disease; DM = diabetes mellitus; DMF = dimethyl fumarate; DMT = disease-modifying therapy; FNG = fingolimod; GA = glatiramer acetate; HTN = hypertension; IFN = interferon; RRMS = relapsing-remitting MS; SPMS = secondary progressive MS; TFL = teriflunomide.

a Partner had the same symptoms as the patient confirmed COVID-19 2 days before patient's symptom onset.

Two patients died. Both of these patients were severely affected by both MS (EDSS 7.517 and 8.5) and COVID-19 (hypoxia, fever, and altered mental status), in addition to having significant comorbidities. On admission, both patients had low absolute lymphocyte counts ( 0.6 and 0.58 $\mathrm{K} / \mathrm{uL}$ ) and one had increased liver function tests (AST 93 and ALT 66), probably because of the COVID-19 infection ${ }^{1}$ because laboratory test results were in the normal range 10 months before for the TFL-treated patient. Both patients were placed on supplemental oxygen, but continued to deteriorate. As per advanced directive of both patients, they were not intubated, and they died 3 and 4 days after the admission, respectively. Autopsy was not performed.

The full scope of COVID-19 manifestations in the MS population remains to be defined. To that end, we encourage all clinicians to follow our example and report their cases of COVID-19 in MS and related disorders in North America (covims.org) and elsewhere (msdataalliance. com). In publishing this initial report, we wanted to share our experiences and observations among patients from a region with early community spread of SARS-CoV-2 in the United States. ${ }^{3}$ We were relieved that most of these infections were mild and in line with observations in general (non-MS) population. At the same time, the fatal outcome in our most disabled patients portends significant risks for patients with advanced MS. Most of our patients remained on their DMTs with no interruption during the COVID-19 infection. However, the generalizability of this finding is limited because none of these were cell-depleting therapies, and most infections were mild. We hope that larger studies will provide more definitive information on additional risks associated with MS DMTs in COVID-19 and hospitalization outcomes to better inform our care for this population.

\section{Study funding}

No targeted funding reported.

\section{Disclosure}

J.D. Bowen, J. Brink, T. Brown, E.B. Lucassen, K. Smoot, A. Wundes, and P. Repovic report no financial disclosures relevant to the topic of this manuscript. Go to Neurology.org/NN for full disclosures.

\section{Publication history}

Received by Neurology: Neuroimmunology \& Neuroinflammation April 14, 2020. Accepted in final form May 7, 2020. 


\section{Appendix Authors}

\begin{tabular}{lll}
\hline Name & Location & Contribution \\
\hline $\begin{array}{l}\text { Pavle } \\
\text { Mepovic, }\end{array}$ & $\begin{array}{l}\text { Swedish MS Center, } \\
\text { Seattle, WA }\end{array}$ & $\begin{array}{l}\text { Designed and conceptualized } \\
\text { study, analyzed the data, and } \\
\text { drafted the manuscript for } \\
\text { intellectual content }\end{array}$ \\
\hline $\begin{array}{l}\text { James D. } \\
\text { Bowen, MD }\end{array}$ & $\begin{array}{l}\text { Swedish MS Center, } \\
\text { Seattle, WA }\end{array}$ & $\begin{array}{l}\text { Major role in the acquisition of } \\
\text { data and revised the manuscript } \\
\text { for intellectual content }\end{array}$ \\
\hline $\begin{array}{l}\text { Justine } \\
\text { Brink, Do, } \\
\text { MPH }\end{array}$ & $\begin{array}{l}\text { Providence MS } \\
\text { Center, Portland, }\end{array}$ & $\begin{array}{l}\text { Major role in the acquisition of } \\
\text { data and revised the manuscript } \\
\text { for intellectual content }\end{array}$ \\
\hline $\begin{array}{l}\text { Ted Brown, } \\
\text { MD, MPH }\end{array}$ & $\begin{array}{l}\text { Evergreen } \\
\text { Healthcare, }\end{array}$ & $\begin{array}{l}\text { Major role in the acquisition of } \\
\text { data and revised the manuscript } \\
\text { for intellectual content }\end{array}$ \\
\hline $\begin{array}{l}\text { Elisabeth B. } \\
\text { Lucassen, } \\
\text { MD }\end{array}$ & $\begin{array}{l}\text { Providence MS } \\
\text { Center, Portland, } \\
\text { Oregon }\end{array}$ & $\begin{array}{l}\text { Major role in the acquisition of } \\
\text { data and revised the manuscript } \\
\text { for intellectual content }\end{array}$ \\
\hline
\end{tabular}

Appendix (continued)

\begin{tabular}{lll}
\hline Name & Location & Contribution \\
\hline $\begin{array}{l}\text { Kyle Smoot, } \\
\text { MD }\end{array}$ & $\begin{array}{l}\text { Providence MS } \\
\text { Center, Portland, } \\
\text { Oregon }\end{array}$ & $\begin{array}{l}\text { Major role in the acquisition } \\
\text { of data and revised the } \\
\text { manuscript for intellectual } \\
\text { content }\end{array}$ \\
\hline $\begin{array}{l}\text { Annette } \\
\text { Wundes, MD }\end{array}$ & $\begin{array}{l}\text { University of } \\
\text { Washington, } \\
\text { Seattle }\end{array}$ & $\begin{array}{l}\text { Major role in the acquisition } \\
\text { of data and revised the } \\
\text { manuscript for intellectual } \\
\text { content }\end{array}$ \\
\hline
\end{tabular}

\section{References}

1. Guan WJ, Ni ZY, Hu Y, et al. Clinical characteristics of coronavirus disease 2019 in China. N Engl J Med 2020;382:1708-1720.

2. Giovannoni G, Hawkes C, Lechner-Scott J, Levy M, Waubant E, Gold J. The COVID19 pandemic and the use of MS disease-modifying therapies. Mult Scler Relat Disord 2020;39:102073.

3. Bhatraju PK, Ghassemieh BJ, Nichols M, et al. Covid-19 in critically ill patients in the Seattle region—case series. N Engl J Med 2020;382:2012-2022. 


\section{Neurology \\ Neuroimmunology \& Neuroinflammation}

COVID-19 in MS: Initial observations from the Pacific Northwest

James D. Bowen, Justine Brink, Ted R. Brown, et al.

Neurol Neuroimmunol Neuroinflamm 2020;7;

DOI 10.1212/NXI.0000000000000783

This information is current as of May 26, 2020

Neurol Neuroimmunol Neuroinflamm is an official journal of the American Academy of Neurology.

Published since April 2014, it is an open-access, online-only, continuous publication journal. Copyright

Copyright $\odot 2020$ The Author(s). Published by Wolters Kluwer Health, Inc. on behalf of the American

Academy of Neurology.. All rights reserved. Online ISSN: 2332-7812.

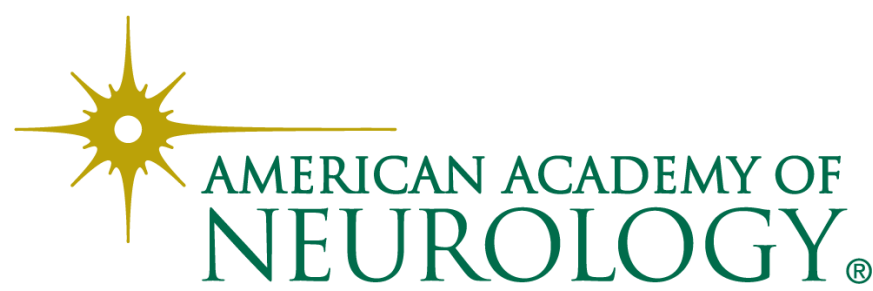




\section{Updated Information \& Services}

References

Citations

Subspecialty Collections

Permissions \& Licensing

Reprints including high resolution figures, can be found at: http://nn.neurology.org/content/7/5/e783.full.html

This article cites 3 articles, 0 of which you can access for free at: http://nn.neurology.org/content/7/5/e783.full.html\#\#ref-list-1

This article has been cited by 3 HighWire-hosted articles: http://nn.neurology.org/content/7/5/e783.full.html\#\#otherarticles

This article, along with others on similar topics, appears in the following collection(s):

All Clinical Neurology

http://nn.neurology.org//cgi/collection/all_clinical_neurology COVID-19

http://nn.neurology.org//cgi/collection/covid_19

Multiple sclerosis

http://nn.neurology.org//cgi/collection/multiple_sclerosis

Viral infections

http://nn.neurology.org//cgi/collection/viral_infections

Information about reproducing this article in parts (figures,tables) or in its entirety can be found online at:

http://nn.neurology.org/misc/about.xhtml\#permissions

Information about ordering reprints can be found online:

http://nn.neurology.org/misc/addir.xhtml\#reprintsus

Neurol Neuroimmunol Neuroinflamm is an official journal of the American Academy of Neurology.

Published since April 2014, it is an open-access, online-only, continuous publication journal. Copyright

Copyright $\odot 2020$ The Author(s). Published by Wolters Kluwer Health, Inc. on behalf of the American

Academy of Neurology.. All rights reserved. Online ISSN: 2332-7812.

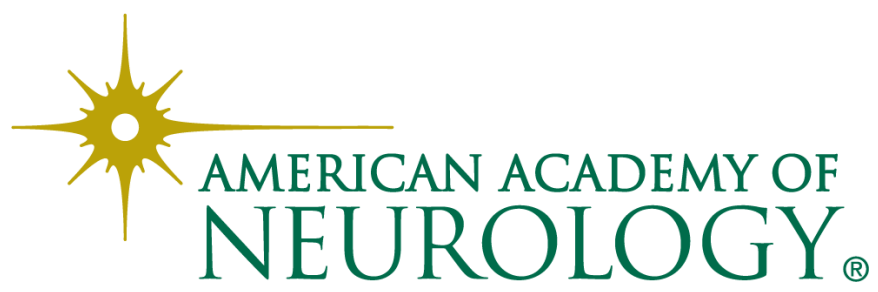

